\title{
RELIGIOSITY AND CORPORATE ILLEGAL ACTIVITY
}

\author{
Joseph E. Coombs \\ Virginia Commonwealth University • Richmond, VA \\ K. Matthew Gilley \\ St. Mary's University • San Antonio, TX \\ Joseph P. O'Connor \\ Recently Retired from the University of Texas at El Paso • El Paso, TX \\ Timothy E. Thorley \\ Dixie High School • St. George, UT \\ Curtis L. Wesley II \\ University of Houston $\bullet$ Houston, TX
}

\section{ABSTRACT}

This paper explores the effects of regional religiosity on the illegal financial actions of business executives. In particular, we examine the extent to which agency and institutional theories may be used to explain fraudulent financial reporting and stock options backdating. Our findings indicate that religiosity has a negative influence on illegal corporate activity but that this relationship is primarily limited to stock options backdating. Board size and independence are also shown to moderate the relationship between religiosity and illegal corporate activity. These results provide support for an institutional theory perspective on mitigating executive opportunism.

Keywords: Corporate Fraud; Executive Compensation; Financial Reporting; Institutional Norms; Religiosity; Stock Options Backdating

\section{INTRODUCTION}

Agency theory is the primary theoretic lens through which executive compensation and corporate governance issues are examined (Dalton, Hitt, Certo, \& Dalton, 2007; Devers, Cannella, Reilly, \& Yoder, 2007; Eisenhardt, 1989). This continues despite growing evidence that agency theory prescriptions may inadvertently contribute to the agency problems they were designed to solve (Dalton et al., 2007; Devers et al., 2007) such as financial fraud (e.g., Ndofor, Wesley, \& Priem, 2015; O'Connor, Priem, Coombs, \& Gilley, 2006) and stock option backdating (Heron and Lie, 2007; Lie, 2005). One possible way to address these issues is to follow Eisenhardt's recommendation that researchers, "use agency theory with complementary theories" (Eisenhardt, 1989, p. 71) because agency theory ignores organizational complexity. We 
follow this recommendation and offer institutional theory as an important compliment to agency theory when studying certain agency problems.

Institutions provide society with rules and standards that influence individuals and organizations, and hence, economic activity (Hitt, Ahlstrom, Dacin, Levitas, \& Svobodina, 2004; North, 1990; Scott, 2001). Institutions affect individuals' and firms' strategic choices (Hitt et al., 2004; Peng, 2003) partly because they define acceptable behaviors within a society (DiMaggio \& Powell, 1983; North, 1990; Scott, 2001). One institutional dimension of particular importance to executives and organizations is the normative dimension. Normative institutions introduce values and norms into social life that "define legitimate means to pursue valued ends" (Scott, 2001, p. 64). In particular, normative institutions not only define socially acceptable goals such as making a profit, but they also specify acceptable rules for meeting those goals (Blake \& Davis, 1964). In our context, we examine how one particular normative institution, religion, influences the likelihood of socially unacceptable actions such as corporate illegal activity. The purpose of our research, then, is to integrate agency and institutional theories and demonstrate how they may act together to explain corporate illegal activity.

In doing so, we make several contributions to the literature. First, we respond to Eisenhardt (1989) by integrating agency and institutional theories to explain corporate illegal activity. Consistent with warnings that agents may look for new ways to increase their personal gain when old ways are monitored and controlled (Dow, 1987; Ghoshal \& Moran, 1996), executives at many organizations have engaged in illegal actions. Agency theory prescriptions have not only failed to mitigate these actions, but may have actually contributed to them (Dalton et al., 2007; Devers et al., 2007). We posit that pressure from normative institutions may help to mitigate these actions.

Second, we develop theory to help understand how normative institutions influence social actors to not engage in corporate illegal activity. More specifically, we explain how religiosity in the geographic region in which an organization is headquartered creates social norms of honesty and risk aversion in which executives live and make decisions (Cialdini \& Goldstein, 2004; Halek \& Eisenhauer, 2001; Kohlberg, 1984; Sunstein, 1996).

Lastly, we extend recent work relating religiosity with legal accounting tactics such as earnings management (Callen, Morel, \& Richardson, 2011; McGuire, Omer, \& Sharp, 2012) and financial restatements (Dyreng, Mayew, \& Williams, 2012), as well as investment and growth rates (Hilary and Hui, 2009) by examining the relationship between religiosity and corporate illegal activity. 


\section{LITERATURE REVIEW}

\section{Religiosity as a Normative Institution}

Religion has been defined as shared beliefs, ideologies, and behaviors based on faith in a higher power, or supernatural forces (Iannaccone 1998). Religiosity is often used in the social sciences to represent the measurable behaviors, affect, and cognitions of respondents that are related to religion (McGuire et al., 2012). Consistent with the view that normative institutions define socially acceptable goals and specify acceptable rules for meeting those goals (Blake \& Davis, 1964), religious norms provide individuals guidelines for what constitutes ethical action (McGuire et al., 2012; Weaver \& Agle, 2002). Within organizations, religiosity may influence honesty and risk aversion, two individual characteristics likely associated with the likelihood to commit illegal (dishonest and risky) acts.

Recent research suggests religiosity, while not consistently associated with honesty (Weaver \& Agle, 2002), remains the best predictor of attitudes about honesty (Katz, Santman, \& Lonero, 1994). This relationship may stem from both a direct and an indirect relationship between religiosity and honesty. For example, Perrin (2000) reported that students were more likely to be honest if they were more religious, as evidenced by church attendance, involvement in religious activities, and belief in life after death, suggesting a direct relationship between religiosity and honesty. This relationship may be indirect as well, however. According to Dyreng and colleagues (2012), religious reminders such as "What Would Jesus Do?" bracelets and religious bumper stickers in more highly religious geographic areas provide a consistent reminder of the region's moral code. Additionally, Mazar, Amir, \& Ariely (2008) demonstrated that religious reminders such as reciting the Ten Commandments tend to curb dishonest reporting that would have led to personal financial gain even for individuals not explicitly associated with any religious group. Further evidence at the organization level suggests religiosity is associated with employees' honesty in terms of their willingness to voluntarily disclose bad news rather than hide it (Dyreng et al., 2012).

Religious individuals are also typically associated with risk aversion more so than are those who are non-religious (Diaz, 2000; Dohmen, Falk, Huffman, Sunde, Schupp, \& Wagner, 2011; Hilary \& Hui, 2009; Liu, 2010; Miller, 2000; Miller \& Hoffman, 1995). Much like the relationship between religiosity and honesty, the relationship between religiosity and risk aversion does not necessarily suggest religious individuals are more risk averse but that the relationship is driven by the social aspect 
of religion (Noussair, Trautmann, van de Kuilen, \& Vellekoop, 2013). Evidence for this relationship also exists at the organization level. Hilary and Hui (2009) found that organizations are more conservative in choosing investments when located in a more religious geographic area. Additionally, Dyreng and colleagues (2012) report that religious adherence is associated with a lower risk of voluntary, rather than forced, financial restatement. The authors of each of these papers suggest their findings provide evidence of social norms influencing corporate decision-making.

\section{Religious Norms and the Organization}

While religiosity is measured at the individual level, there is reason to conclude that individual religiosity can influence decisions at the organization level. Religious norms of the population located around an organization's headquarters are one aspect of the social environment in which organization decisions are made (Cialdini \& Goldstein 2004; Dyreng et al., 2012; Kohlberg, 1984; Sunstein, 1996). Even when managers themselves are not religious, the likelihood of interacting with religious individuals exposes managers to religious social norms and increases the likelihood that managers are influenced by these norms (Kennedy \& Lawton, 1998). As evidence of this relationship, Welch, Tittle, and Petee (1991) found that religious social norms in a community can cause individual adherence to these social norms. More specifically, Welch and colleagues (1991) demonstrated both individual and community religiosity influenced whether an individual would evade taxes or use employer equipment for personal gain.

\section{Religiosity and Financial Reporting}

In some cases, managers manipulate earnings to bolster their own financial rewards, or to create a false sense of security for key stakeholders regarding the company's finances. In a study looking at both religiosity and other cultural variables, Callen and colleagues (2011) found that earnings management is unrelated to both religious affiliation and religiosity, as measured by attendance and self-ratings of religious conviction and importance. However, other cultural variables, individualism and uncertainty avoidance, had a relationship with earnings management. These variables were examined at the national level, so it is possible that differences in religiosity within a particular country may relate to earnings management. In a working paper, Grullon, Kanatas, and Weston (2014) found that organizations in areas with a higher level of per capita adherents to an organized religion were less likely to be the targets of class action lawsuits, engage in forms of options backdating 
that are not illegal per se, and manipulate their earnings. However, as they note, their rather coarse-grained measure of religiosity presents limitations.

McGuire and colleagues (2012) found that social norms created or influenced by religion help to reduce financial reporting irregularities, especially when other control mechanisms are less effective. As with other studies, these results may suggest that the manager making a decision does not have to be particularly religious in order to be influenced by the religious practices, attachment, and affiliation in the region in which he or she works. Dyreng and colleagues (2012) examined different aspects of financial reporting and found similar results. More specifically, they determined that non-forced restatements, made necessary by inappropriate reporting or omissions, are less likely in more religious areas. They also found that firms located in more religious areas do not delay or avoid reporting bad news as much as firms located in less religious areas. Whether these reporting practices reflect the values adopted by executives because of the area in which they work, or represent a response to social norms and pressures from stakeholders, is unclear.

\section{Corporate Illegal Behavior}

There is an extensive body of work on corporate illegal activity, which we define as deliberate actions taken by executives to misrepresent their firm's operations and financial activities for monetary gain. This definition covers issues such as fraudulent financial reporting (Arthaud-Day, Certo, Dalton, \& Dalton, 2006; Harris \& Bromiley, 2007; Ndofor et al., 2015; O’Connor et al., 2006; Zhang, Bartol, Smith, Pfarrer, \& Khanin, 2008) and stock option backdating (Aboody \& Kasznik, 2000; Heron \& Lie, 2007; Lie, 2005).

Harris and Bromiley (2007) reported that fraudulent financial reporting increased when stock options made up a higher percentage of total compensation. Ndofor and colleagues (2015) describe how industry and firm level complexity are associated with fraud, while CEO stock options increase the likelihood of fraud in association with high industry complexity. O'Connor and colleagues (2006) found that fraudulent financial reporting and stock option grants were related when boards of directors also held options. According to Zhang and colleagues (2008), fraudulent financial reporting is more likely to occur when CEOs hold greater amounts of "out of the money" options. A common thread amongst these studies is that CEO stock options are associated with fraudulent financial reporting. For agency theorists, this is problematic, as stock options are the primary mechanism used to reduce opportunistic behavior by aligning the interests of agents and principals (Eisenhardt, 1989; Fama \& Jensen, 1983; Jensen \& Meckling, 1976). 
Stock option backdating occurs when stock option grant dates are changed (1) with the benefit of hindsight to a past date when the stock price was appreciably lower and (2) without notifying or obtaining approval from principals (Lie, 2005). Because most stock option plans limit the number of shares awarded annually, and because options are typically granted "at the money" (the price of the firm's common stock on the day the options are granted), backdating provides an illegal and "covert method of maximizing the option component value of executives' compensation" (Heron \& Lie, 2007, p. 274).

Researchers have provided substantial evidence that backdating is widespread (Aboody \& Kasznik, 2000; Heron \& Lie, 2007, 2009; Heron, Lie, \& Perry, 2007; Lie, 2005; Narayanan, Schipani, \& Seyhun, 2007; Narayanan \& Seyhun, 2008) and, despite regulatory changes, continues to be a significant issue. Specifically, researchers estimate that the enhanced regulations instituted through the SarbanesOxley Act of 2002 (SOX) have reduced backdating events by only half (Heron and Lie, 2009), and that 20 percent of stock grants do not conform to SOX's reporting requirements (Narayanan \& Seyhun, 2008). Consistent with their expectation, Aboody and Kasznik (2000) reported changes in stock prices and analyst earnings forecasts around option awards consistent with stock option backdating. Heron and Lie (2007) reported that stock returns are abnormally negative before option grants and abnormally positive afterward options grants in a large sample of public firms, suggesting backdating is widespread. In a subsequent study, Heron and Lie (2009) provided evidence that from 1996-2005, 13.6\% of all option grants to top executives were backdated or manipulated. Narayanan and colleagues (2007) calculated an average loss to shareholders of about $8 \%$ in firms where executive stock options were backdated. Lastly, Narayanan and Seyhun (2008) report evidence of both stock option backdating and forward dating. Perhaps even more problematic for agency theorists, stock option backdating results suggest executives are manipulating the very mechanism designed to reduce their opportunistic behavior (Eisenhardt, 1989; Fama \& Jensen, 1983; Jensen \& Meckling, 1976).

\section{HYPOTHESIS DEVELOPMENT}

We theorize that religious social norms affect corporate illegal activity through their influence on executive decision-making. The primary focus of previous corporate illegal activity research has been on how firm financial reports and stock options have been manipulated to the benefit of executives. A primary focus of a second research stream examined how religiosity influenced several accounting 
tactics legally used to benefit organizations. Religiosity can also be examined in terms of its relationship with corporate illegal activity, which is the purpose of the current study. Religious individuals within a particular geographic area interact with employees and executives from local firms, and in doing so, expose these organization members to religious social norms prevalent in the area (Kennedy and Lawton, 1998). We posit that religious social norms such as honesty (Dyreng et al., 2012; Mazar et al., 2008) and risk aversion (Diaz, 2000; Dyreng et al., 2012; Hilary \& Hui, 2009; Miller, 2000; Miller \& Hoffman, 1995) influence accounting tactics such that the likelihood of using these tactics is lower in areas with higher religiosity. To the extent that religious social norms are prevalent in the community, we expect executives to be influenced by these norms when considering whether to take illegal actions. More specifically, when located in a community with higher religiosity, we expect executives to adhere to the accompanying religious social norms and be more honest and risk averse. Executives in more religious communities are less likely to commit illegal acts because other executives or employees, similarly influenced by religious social norms, are likely to view such actions as unethical (McGuire et al., 2012). Taken together, these arguments suggest executives in organizations headquartered in more religious communities will be less likely to commit illegal acts. More specifically, we propose:

Hypothesis 1: Regional religiosity negatively affects corporate illegal activity.

\section{Board of Director Size as a Moderator}

Agency theory suggests that boards of directors can be important monitors of the agent-principle relationship (Fama, 1980; Fama \& Jensen, 1983; Jensen \& Meckling, 1976). There remains uncertainty, however, amongst research as to whether larger or smaller boards are more effective monitors of management actions (Williams, Fadil, \& Armstrong, 2005). From an agency perspective, there are several reasons larger boards may be better monitors than smaller boards. First, larger boards have more specialized human capital than smaller boards and may, therefore, be better able to process larger quantities of information more quickly, thus decreasing information asymmetries between management and shareholders (Amason \& Sapienza, 1997; Williams et al., 2005). Larger boards may also be able to form and use more committees with which to monitor management (Pearce \& Zahra, 1992; Zahra \& Pearce, 1989). Additionally, larger boards likely have more independent board members with which to monitor the executives. In addition, larger boards 
are better able to constrain executives' internal political coalitions (Ocasio, 1994; Williams et al., 2005). Multiple political coalitions are more easily formed in larger boards, and these coalitions may be more effective in confronting political coalitions within the executive ranks (Ocasio, 1994). Lastly, larger boards may be more likely to be represented by members of the community who are of a religious orientation, thus affecting executive decision-making. These arguments suggest that executives who are not sufficiently influenced to avoid illegal acts by religious social norms may be further influenced to avoid such actions by larger boards. In other words, we expect that board size and regional religiosity interact such that the negative effects of religiosity on illegal activity are enhanced when a company's board is larger. Therefore, we propose:

Hypothesis 2: Board size moderates the effects of religiosity on corporate illegal activity, such that the negative relationship between religiosity and corporate illegal activity will be stronger in organizations with a larger board of directors.

\section{Percentage of Outsiders on the Board as a Moderator}

In addition to board size, agency theory suggests boards with a higher percentage of outsiders can better monitor executive actions (Mizruchi, 1983; Zahra $\&$ Pearce, 1989). The belief is that outside directors, as a result of their independence from management, will produce superior firm performance (Dalton, Daily, Ellstrand, \& Johnson, 1998). Ezzamel and Watson (1993) provide support for this perspective with their finding that board outsiders were associated with greater firm profitability. Other researchers, such as Baysinger and Butler (1985) and Pearce and Zahra (1992), have also reported results consistent with outside board members' ability to monitor management and deliver greater firm performance. This research suggests that when executives are not sufficiently influenced to avoid illegal acts by religious social norms, more independent boards may further influence executives to avoid such actions. Thus:

Hypothesis 3: Board independence moderates the relationship between religiosity and corporate illegal activity, such that the negative effects of religiosity on corporate illegal activity will be stronger in organizations with more independent boards. 


\section{METHODOLOGY}

\section{Sample Selection}

Our sample contains firms that have been involved in illegal corporate activity, including reporting fraudulent financial results and backdating stock options. These illegal acts are relatively rare, making random sampling inappropriate, necessitating use a matched pair design (O'Connor et al., 2006). Consistent with O'Connor and colleagues (2006), to identify firms that had fraudulently inflated financial results, we reviewed 12,222 articles using the ProQuest ${ }^{\circledR}$ Newspapers database of over 550 newspapers and searched for variations of the word "restate" in the text of fulltext articles. To identify firms with specific instances of backdating, we used The Wall Street Journal online Options Scorecard. Janney and Gove (2011) used the full database to study relationships between corporate social responsibility and stock option backdating. To ensure firms in our sample were unambiguously involved with backdating, firms had to meet one of three criteria: (1) the firm admitted that certain historical stock option grants were found to differ from the recorded grant dates, or (2) the firm restated financial results for costs related to backdating, or (3) the firm settled backdating charges with the federal government. The backdating firms included in this sample had at least one instance of backdating.

Next, to provide a comparison group (non-restating and backdating firms), we developed a matched-sample design (Denis, Hanouna, \& Sarin, 2006; Harris \& Bromiley, 2007; O’Connor et al., 2006) by closely matching each firm that had committed an illegal act with a similar firm based on five criteria. All matched firms (1) are publicly traded, (2) are based in the U.S. as of the year corresponding to the backdating, (3) share four-digit standard industry classification codes (SIC), (4) have

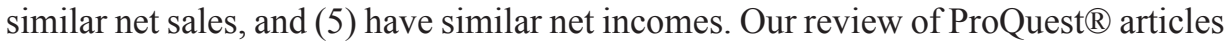
identified 103 firms that met our criteria, and we were able to identify close matches for 65 firms. Our review of the The Wall Street Journal online Options Scorecard included fourteen backdating firms that we dropped because the necessary financial data were unavailable or they were headquartered outside of the U.S., leaving 82 firms for our analyses. Thus, the final sample included 65 firms that had been forced to restate their financial reports and 82 backdating firms. Including the matched firms, our sample totals 294 firms, of which 130 make up the forced restatement group and 164 are in the backdating group. 
Because the exact date of each instance of illegal activity is typically not identifiable, we incorporate a one-year lag in our models. Thus, if a firm was investigated for backdating or restated earnings in year $t$, data for all independent and control variables were collected for year t-1 (except for value of exercisable options, discussed below, which were collected for year $\mathrm{t}$ ). This lag structure is appropriate since CEO compensation (including stock options) is determined annually and is influenced by firm performance in the prior year (Coombs \& Gilley, 2005). The data sources for all variables are The Wall Street Journal online Options Scorecard, the ProQuest ${ }^{\circledR}$ Newspapers database, Compustat, Execucomp, and the SEC's EDGAR database.

\section{Dependent Variables}

The dependent variable is corporate illegal activity, which is a binary variable coded as 1 if the firm committed an illegal activity (either backdating or forced restatements) and 0 if the firm did not. A binary variable is used because whether a firm committed an illegal act is a dichotomous phenomenon and because assigning a specific dollar amount for the financial consequences of these illegal acts requires consideration of numerous arbitrary factors.

\section{Control Variables}

Twelve control variables are used in the analyses. Executives in larger firms may be more likely to commit illegal acts because they may face more pressure to suppress their values if they hinder organizational priorities (Gabbioneta, Greenwood, Mazzola, \& Minoja, 2013). Thus, we control for firm size using the natural logarithm of total sales. We control for the number of audit committee meetings held annually (O'Connor et al., 2006), as the number of audit committee meetings may decrease the likelihood of illegal acts (Ndofor et al., 2015; O'Connor et al., 2006). CEO age is used as a control variable because of its relationship with both managerial risk propensity and moral judgment (Zahra, Priem, \& Rasheed, 2005) as well as its negative relationship with financial misconduct (O’Connor et al., 2006). CEO age is measured in years. CEO cash compensation is measured as the sum of salary and bonus cash compensation. 
Higher CEO cash compensation might be expected to decrease CEO motivation to commit illegal acts (Finkelstein and Boyd, 1998; Henderson and Fredrickson, 1996). Stock option grants are the very mechanism through which executives have enriched themselves, whether it is from fraudulent financial reporting or stock option backdating. We expect more option grants to increase the likelihood that executives will commit illegal acts. Stock option grants are measured as the number of stock options the CEO received in the year of the organization's illegal act. CEO tenure is associated with experience and power (Shen, 2003) and is measured as the number of years the CEO has held that title at the focal firm. CEO duality is measured as 1 if the CEO is also the chair of the board of directors and 0 if the CEO is not, and it is considered a measure of CEO power (Harris \& Bromiley, 2007). CEO ownership is measured as the percentage of stock owned by the CEO (Zhang et al., 2008). We expect that when CEOs have higher ownership they have less motivation to commit illegal acts. As Harris and Bromiley (2007) note, poor performance against historic company standards motivates executives to respond. As a result, self reference equals 1 where the firm's return on assetst- 1 minus its return on assetst- 2 is positive and 0 if not (Harris \& Bromiley, 2007). Board of directors (BOD) options is a binary variable reflecting the presence (1) or absence (0) of BOD stock options. Hambrick and Jackson (2000) provided evidence that companies with directors who own company stock outperform other firms, suggesting these options may align board member interests with shareholder interests.

\section{Moderators}

Williams and colleagues (2005) recently argued that larger boards are better able to monitor executive actions because larger boards may process larger quantities of information more quickly, thus decreasing information asymmetries between management and shareholders. Larger boards may also form and use more committees with which to monitor management, and they are better able to constrain executives' political coalitions. Board members are measured as the total number of board members for each firm. Percentage of outsiders on the board (Abrahamson \& Park, 1994) was measured as the number of outsiders divided by the total number of directors. 


\section{Independent Variable}

Religiosity is the independent variable in our analyses. To create our measure, we followed the process used by McGuire and colleagues (2012). We used a Gallup organization database of over 610,000 interviews conducted nationwide on a range of religious characteristics and focused on three of religiosity's distinct elements: cognitive, affective, and behavioral (Parboteeah, Hoegl, \& Cullen, 2008). Consistent with McGuire and colleagues (2012), we used three poll questions that correspond with the three elements of religiosity: (1) Are you affiliated with a particular religion (cognitive); (2) Is religion important in your daily life (affective); and (3) Do you attend religious services weekly (behavioral). Data for these questions is available at the county level. We grouped counties into metropolitan statistical areas (MSAs) and aggregated scores for each question into an MSA-level score. We then changed the scores for each question into Z-scores and summed these results to create MSAlevel scores for religiosity.

\section{DATA ANALYSIS AND RESULTS}

To test our hypotheses, we use logistic regression, which is appropriate for analyzing models with dichotomous dependent variables (Hoetker, 2007). Conditional logistic regression is typically used with dichotomous dependent variables when the sample follows a matched-pair design (Agresti, 2002); however, it does not provide an intercept necessary for graphing interaction results. So to confirm our logistic regression results, we also tested our hypotheses with conditional logistic regression and found consistent results. We also follow Hoetker's (2007) and Wiersema and Bowen's (2009) suggestions to report marginal effects when interpreting direct effects between independent variables and the dependent variable. Consistent with Sanders and Hambrick (2007), we report one-tailed tests for our hypothesized interactions and two-tailed results for our control variables. Lastly, all variables (except for binary variables) were mean centered before hypothesis testing. Table I reports uncentered descriptive statistics and correlations for the variables. 
Table 1

\section{Correlation Matrix}

\begin{tabular}{|l|c|c|c|c|c|c|c|c|c|c|c|}
\hline & Mean & S.D. & 1. & 2. & 3. & 4. & 5. & 6. & 7. & 8. & 9. \\
\hline 1. Illegal Activity & 0.50 & 0.50 & & & & & & & & & \\
\hline 2. Backdating & 0.50 & 0.50 & 1.00 & & & & & & & & \\
\hline 3. False Statement & 0.50 & 0.50 & 1.00 & n.a. & & & & & & & \\
\hline 4. Religiosity - Illegal Activity & 0.00 & 2.92 & -0.07 & -0.17 & 0.05 & & & & & & \\
\hline 5. Religiosity - Backdating & 0.00 & 2.93 & -0.17 & -0.17 & n.a. & 1.00 & & & & & \\
\hline 6. Religiosity - False Statement & 0.00 & 2.90 & 0.05 & n.a. & 0.05 & 1.00 & n.a. & & & & \\
\hline 7. Firm Size & 5.78 & 2.32 & -0.02 & 0.01 & -0.04 & 0.20 & 0.06 & 0.13 & & & \\
\hline 8. Auditor Meetings & 4.40 & 3.99 & 0.08 & 0.00 & 0.15 & 0.13 & -0.07 & 0.06 & 0.34 & & \\
\hline 9. CEO Age & 49.53 & 13.94 & -0.13 & -0.17 & -0.13 & 0.19 & 0.26 & 0.21 & 0.18 & 0.23 & \\
\hline 10. Cash Compensation & 7.97 & 8.72 & -0.03 & 0.08 & -0.09 & 0.20 & 0.07 & 0.16 & 0.54 & 0.26 & 0.27 \\
\hline 11. Option Grants & 3.57 & 10.09 & 0.11 & 0.15 & 0.09 & 0.07 & 0.06 & 0.08 & 0.16 & 0.13 & 0.01 \\
\hline 12. CEO Tenure & 7.16 & 7.27 & 0.02 & 0.01 & 0.02 & 0.04 & 0.12 & 0.07 & -0.10 & -0.02 & 0.38 \\
\hline 13. CEO Duality & 0.69 & 0.46 & 0.03 & -0.01 & 0.09 & 0.18 & 0.17 & 0.13 & 0.11 & 0.03 & 0.11 \\
\hline 14. CEO Ownership & 0.07 & 0.13 & 0.07 & 0.09 & 0.02 & -0.00 & 0.12 & -0.03 & -0.21 & -0.13 & 0.15 \\
\hline 15. Self Reference & 0.45 & 0.50 & 0.03 & 0.12 & -0.10 & 0.01 & 0.13 & 0.06 & -0.01 & -0.01 & -0.03 \\
\hline 16. Board Options & 0.76 & 0.43 & -0.03 & -0.06 & 0.00 & -0.16 & -0.18 & -0.09 & -0.10 & 0.03 & -0.18 \\
\hline 17. Board Members & 7.60 & 3.37 & -0.01 & 0.01 & -0.02 & 0.37 & 0.35 & 0.31 & 0.52 & 0.34 & 0.50 \\
\hline 18. Outsiders on the Board & 0.69 & 0.21 & -0.01 & -0.02 & -0.00 & 0.12 & 0.05 & 0.16 & 0.31 & 0.38 & 0.67 \\
\hline
\end{tabular}

Values above 0.11 or below -0.11 are significant at 0.05 .

n.a.: Cannot be computed because at least one variable is constant.

\section{Table 1 (cont.)}

\section{Correlation Matrix}

\begin{tabular}{|l|c|c|c|c|c|c|c|c|}
\hline & 10. & 11. & 12. & 13. & 14. & 15. & 16. & 17. \\
\hline 1. Illegal Activity & & & & & & & & \\
\hline 2. Backdating & & & & & & & & \\
\hline 3. False Statement & & & & & & & & \\
\hline 4. Religiosity - Illegal Activity & & & & & & & & \\
\hline 5. Religiosity - Backdating & & & & & & & & \\
\hline 6. Religiosity - False Statement & & & & & & & & \\
\hline 7. Firm Size & & & & & & & & \\
\hline 8. Auditor Meetings & & & & & & & & \\
\hline 9. CEO Age & & & & & & & & \\
\hline 10. Cash Compensation & & & & & & & & \\
\hline 11. Option Grants & 0.01 & & & & & & & \\
\hline 12. CEO Tenure & -0.03 & -0.09 & & & & & & \\
\hline 13. CEO Duality & 0.09 & 0.05 & 0.23 & & & & & \\
\hline 14. CEO Ownership & -0.22 & -0.04 & 0.39 & 0.21 & & & & \\
\hline 15. Self Reference & -0.01 & -0.09 & 0.00 & 0.05 & 0.05 & & & \\
\hline 16. Board Options & -0.18 & 0.04 & -0.15 & -0.02 & -0.13 & 0.04 & & \\
\hline 17. Board Members & 0.49 & 0.14 & -0.03 & 0.03 & -0.18 & -0.05 & -0.13 & \\
\hline 18. Outsiders on the Board & 0.31 & 0.08 & 0.06 & 0.01 & -0.11 & -0.02 & -0.01 & 0.56 \\
\hline
\end{tabular}

Values above 0.11 or below -0.11 are significant at 0.05 . 
Table 2

\section{Logistic Regression Results for Religiosity and Illegal Financial Activity (Includes Backdating and Forced Restatements)}

\begin{tabular}{|l|c|c|c|c|c|}
\hline & Model 1 & Model 2 & $\begin{array}{c}\text { Model 3 } \\
\text { Marginal } \\
\text { Effects }\end{array}$ & Model 4 & $\begin{array}{c}\text { Model 5 } \\
\text { Marginal } \\
\text { Effects }\end{array}$ \\
\hline Firm Size & -0.07 & -0.07 & -0.02 & -0.06 & -0.02 \\
\hline Audit Meetings & $0.06^{\dagger}$ & $0.07^{\dagger}$ & $0.02^{\dagger}$ & $0.07^{\dagger}$ & $0.02^{\dagger}$ \\
\hline CEO Age & $-0.06^{* * *}$ & $-0.06^{* * *}$ & $-0.01^{* * *}$ & $-0.05^{* * *}$ & $-0.01^{* * *}$ \\
\hline Cash Compensation & 0.00 & -0.00 & -0.00 & -0.00 & -0.00 \\
\hline Stock Options Granted & $0.03^{\dagger}$ & $0.03^{\dagger}$ & $0.01^{\dagger}$ & $0.03^{\dagger}$ & $0.01^{\dagger}$ \\
\hline CEO Tenure & 0.03 & 0.03 & 0.01 & 0.03 & 0.01 \\
\hline CEO Duality & 0.10 & 0.17 & 0.04 & 0.17 & 0.04 \\
\hline CEO Ownership & 1.85 & 1.86 & 0.47 & $1.95^{\dagger}$ & $0.49^{\dagger}$ \\
\hline Self Dum & 0.13 & 0.15 & 0.04 & 0.12 & 0.03 \\
\hline Board Options & -0.39 & -0.44 & -0.11 & -0.47 & -0.12 \\
\hline Board Members & 0.05 & 0.07 & 0.02 & 0.07 & 0.02 \\
\hline Outsider Percentage & $1.78^{\dagger}$ & $1.63^{\dagger}$ & $0.41^{\dagger}$ & 1.26 & 0.32 \\
\hline Religiosity & & $-0.07^{\dagger}$ & $-0.02^{\dagger}$ & -0.07 & -0.02 \\
\hline Religiosity x Board Members & & & & $0.03^{*}$ & $0.01^{*}$ \\
\hline $\begin{array}{l}\text { Religiosity x Outsider } \\
\text { Percentage }\end{array}$ & & & & $-0.75^{* *}$ & $-0.19^{* *}$ \\
\hline Chi-Square & $25.31^{*}$ & $27.32^{*}$ & & $34.03^{* *}$ & \\
\hline-2 Log Likelihood & 382.26 & 380.25 & & 373.55 & \\
\hline Nagelkerke R & 0.11 & 0.12 & & 0.15 & \\
\hline N & 294 & 294 & & 294 & \\
\hline
\end{tabular}

$p<.05$
${ }_{*} p<.01$
${ }^{* *} p<.001$

Results for Hypothesis 1 are shown in Model 2 of Table II. Hypothesis 1 argued that religiosity is negatively associated with corporate illegal activity. Results from Model 2 support the statistical significance of this relationship, although the relationship is weak. This result suggests that religiosity does have a weak but significant negative influence on illegal corporate activity. Results for Hypotheses 2 and 3 are shown in Model 4 of Table II. Hypothesis 2 argues that board size moderates the relationship between religiosity and corporate illegal activity, such that the negative relationship between religiosity and corporate illegal activity will be stronger in organizations with a larger board of directors. Hypothesis 2 is not supported. The interaction between religiosity and board size is positive and our plot of these results confirms that larger boards actually increase the likelihood of backdating as the level of religiosity rises. Hypothesis 3 stated that board independence moderates of the relationship between religiosity and corporate illegal activity, such that the negative relationship between 
religiosity and corporate illegal activity will be stronger in organizations with more independent boards. Our results provide support for Hypothesis 3 and our plot of this relationship lends further support.

\section{Figure 1}

\section{Interaction Between Religiosity and Board Size}

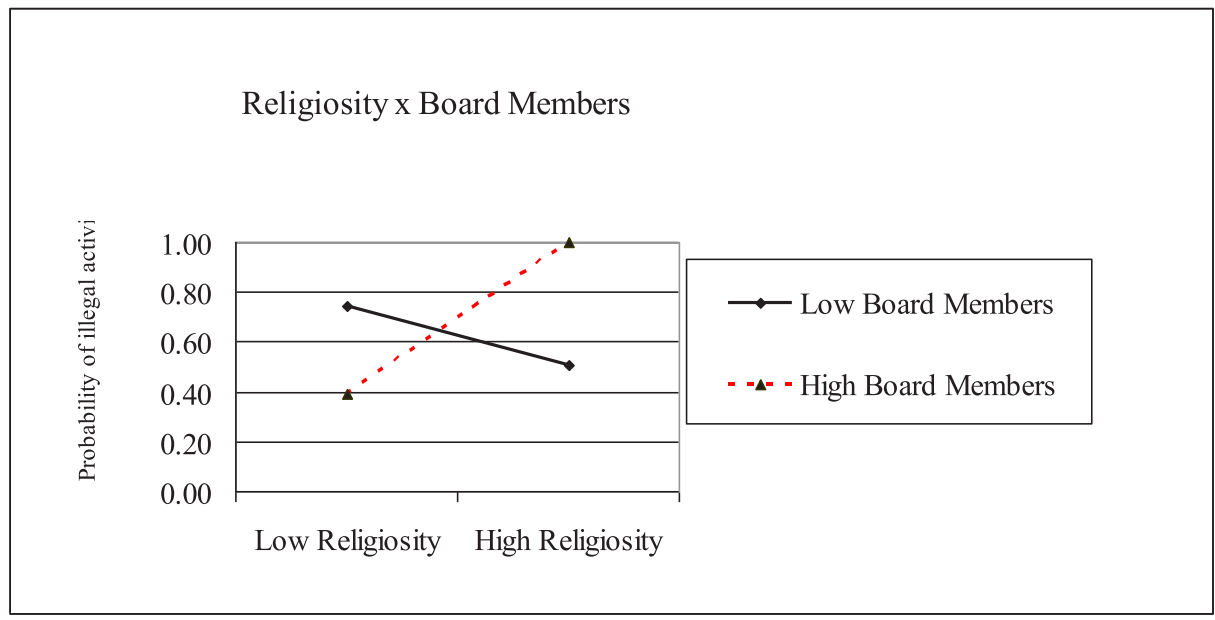

Figure 2

Interaction Between Religiosity and Outsider Percentage

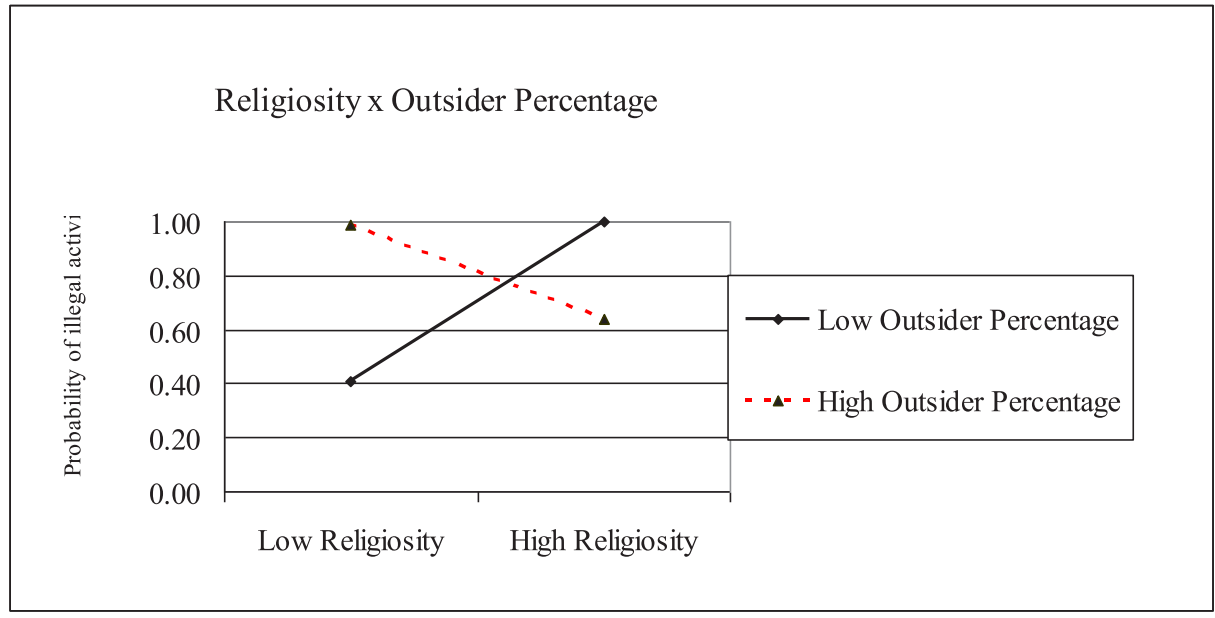

To determine whether our results were consistent across different types of illegal acts, we also conducted the above analyses separately for only firms that restated financial results and for only firms where stock options were backdated. Interestingly, for firms that restated their financials, there was no significant 
relationship between religiosity and restatements. Further, the interaction of religiosity and board size was not significant. The interaction of religiosity and board outsider percentage, however, was negative and significant suggesting that religiosity can still influence restatements, and that the influence is enhanced by board independence. Regarding firms where stock option backdating occurred, religiosity had a highly significant, negative influence, suggesting that religiosity by itself may serve to limit stock option backdating. Further, the interaction between religiosity and board size is significant and positive as in our original set of analyses, suggesting that larger boards inhibit the influence of religiosity on stock option backdating. The interaction between religiosity and percentage of outsiders on the board is not significant, indicating that board independence does not enhance the effect of religiosity on stock option backdating.

Table 3

\section{Logistic Regression Results for Religiosity and Forced Restatements}

\begin{tabular}{|l|c|c|c|c|c|}
\hline & Model 1 & Model 2 & $\begin{array}{c}\text { Model 3 } \\
\text { Marginal } \\
\text { Effects }\end{array}$ & Model 4 & $\begin{array}{c}\text { Model 5 } \\
\text { Marginal } \\
\text { Effects }\end{array}$ \\
\hline Firm Size & -0.14 & -0.13 & -0.03 & -0.17 & -0.04 \\
\hline Audit Meetings & $0.12^{*}$ & $0.12^{*}$ & $0.03^{*}$ & $0.13^{*}$ & $0.03^{*}$ \\
\hline CEO Age & $-0.09^{* * *}$ & $-0.09^{* * *}$ & $-0.02^{* * *}$ & $-0.10^{* * *}$ & $-0.03^{* * *}$ \\
\hline Cash Compensation & -0.02 & -0.02 & -0.01 & -0.02 & -0.01 \\
\hline Stock Options Granted & 0.01 & 0.01 & 0.01 & 0.01 & 0.01 \\
\hline CEO Tenure & 0.03 & 0.03 & 0.01 & 0.03 & 0.01 \\
\hline CEO Duality & $0.90^{\dagger}$ & $0.85^{\dagger}$ & $0.21^{\dagger}$ & $0.92^{\dagger}$ & $0.23^{\dagger}$ \\
\hline CEO Ownership & -0.15 & 0.08 & 0.02 & 0.19 & 0.05 \\
\hline Self Dum & $-0.73^{\dagger}$ & $-0.77^{\dagger}$ & $-0.19^{\dagger}$ & $-0.87^{\dagger}$ & $-0.22^{\dagger}$ \\
\hline Board Options & -0.52 & -0.50 & -0.12 & -0.53 & -0.13 \\
\hline Board Members & 0.06 & 0.04 & 0.01 & 0.07 & 0.02 \\
\hline Outsider Percentage & $4.39^{*}$ & $4.63^{*}$ & $1.16^{*}$ & $3.97^{*}$ & $0.99^{*}$ \\
\hline Religiosity & & 0.07 & 0.02 & 0.12 & 0.03 \\
\hline Religiosity x Board Members & & & & 0.00 & 0.00 \\
\hline Religiosity x Outsider & & & & $-1.01^{*}$ & $-0.25^{*}$ \\
Percentage & & & & & $30.68^{* *}$ \\
\hline Chi-Square & $23.54^{*}$ & $24.44^{*}$ & & 149.54 & \\
\hline-2 Log Likelihood & 156.68 & 155.78 & & 0.28 & \\
\hline Nagelkerke R & 0.22 & 0.23 & & 130 & \\
\hline N & 130 & 130 & & & \\
\hline
\end{tabular}

\footnotetext{
* $\mathrm{p}<.05$

** $\mathrm{p}<.01$

${ }^{* * *} \mathrm{p}<.001$
} 
Table 4

\section{Logistic Regression Results for Religiosity and Stock Option Backdating}

\begin{tabular}{|l|c|c|c|c|c|}
\hline & Model 1 & Model 2 & $\begin{array}{c}\text { Model 3 } \\
\text { Marginal } \\
\text { Effects }\end{array}$ & Model 4 & $\begin{array}{c}\text { Model 5 } \\
\text { Marginal } \\
\text { Effects }\end{array}$ \\
\hline Firm Size & -0.10 & -0.14 & -0.03 & -0.15 & -0.04 \\
\hline Audit Meetings & 0.01 & -0.00 & -0.00 & 0.00 & 0.00 \\
\hline CEO Age & $-0.06^{* *}$ & $-0.05^{*}$ & $-0.01^{*}$ & $-0.05^{*}$ & $-0.01^{*}$ \\
\hline Cash Compensation & 0.08 & $0.09^{\dagger}$ & $0.02^{\dagger}$ & 0.07 & 0.02 \\
\hline Stock Options Granted & $0.07^{*}$ & $0.07^{*}$ & $0.02^{*}$ & $0.07^{\dagger}$ & $0.02^{\dagger}$ \\
\hline CEO Tenure & 0.04 & 0.04 & 0.01 & 0.05 & 0.01 \\
\hline CEO Duality & -0.28 & -0.12 & -0.03 & -0.11 & -0.03 \\
\hline CEO Ownership & 2.13 & $2.64^{\dagger}$ & $0.66^{\dagger}$ & $2.67^{\dagger}$ & $0.67^{\dagger}$ \\
\hline Self Dum & 0.52 & $0.69^{\dagger}$ & $0.17^{\dagger}$ & $0.70^{\dagger}$ & $0.17^{\dagger}$ \\
\hline Board Options & -0.55 & -0.64 & -0.16 & -0.62 & -0.16 \\
\hline Board Members & -0.07 & 0.02 & 0.01 & 0.04 & 0.01 \\
\hline Outsider Percentage & 0.71 & 0.91 & 0.22 & 0.78 & 0.19 \\
\hline Religiosity & & $-0.18^{* *}$ & $-0.05^{* *}$ & $-0.23^{* *}$ & $-0.06^{* *}$ \\
\hline Religiosity x Board Members & & & & $0.06^{*}$ & $0.02^{*}$ \\
\hline Religiosity x Outsider Percentage & & & & -0.60 & -0.15 \\
\hline Chi-Square & $21.23^{*}$ & $27.85^{* *}$ & & $33.58^{* *}$ & \\
\hline-2 Log Likelihood & 206.12 & 199.50 & & 193.78 & \\
\hline Nagelkerke R & 0.16 & 0.21 & & 0.25 & \\
\hline N & 164 & 164 & & 164 & \\
\hline
\end{tabular}

* $\mathrm{p}<.05$

${ }^{* *} \mathrm{p}<.01$

${ }^{* * *} \mathrm{p}<.001$

\section{DISCUSSION}

Our study was motivated by the desire to extend theory by integrating institutional theory (North, 1990; Scott, 2001) with agency theory (Fama \& Jensen, 1983; Jensen \& Meckling, 1976) as suggested by Eisenhardt (1989). In doing so, we introduced religiosity as a normative institutional construct that may reduce the likelihood of agent-based opportunism in the form of illegal corporate activity. We view illegal corporate activity as a form of opportunistic behavior that has been largely overlooked because research has focused on more easily observable forms of opportunism (Dow, 1987; Ghoshal \& Moran, 1996). We focus on forced financial restatements and stock option backdating as forms of illegal corporate activity because the SEC has formally recognized these activities as fraudulent and because stock options have been viewed as aligning interests of agents and principals (Eisenhardt, 1989). Moreover, these forms of opportunism are less researched than 
other forms, such as excessive compensation.

Our research makes three specific contributions of interest to institutional and agency theory researchers. First, we take up Eisenhardt's (1989) call to integrate agency theory with other complementary theories by introducing institutional theory to explain how corporate illegal activity may be reduced. Corporate illegal activity is particularly important to understand, as it may reflect executives' attempts to increase their personal gain to offset compensation reductions resulting from increased monitoring in other areas (Dow, 1987; Ghoshal \& Moran, 1996). Eisenhardt's (1989) suggestion to draw from other theories is particularly timely because agency theory prescriptions to mitigate opportunism appear to have increased other forms of opportunism (Dalton et al., 2007; Devers et al., 2007). We posit that pressure from normative institutions may help to mitigate these new forms of opportunism.

Second, we develop theory to clarify how normative institutions may influence social actors such as executives to not engage in corporate illegal activity. More specifically, we introduce religiosity as a normative institutional concept and explain how the level of religiosity in the geographic region around an organization's headquarters forms social norms of honesty and risk aversion in which executives live and make decisions (Cialdini \& Goldstein, 2004; Halek \& Eisenhauer, 2001; Kohlberg, 1984; Sunstein, 1996). Additionally, we explain how institutional norms are transferred from the social to the organizational level and discuss how these institutional norms interact with board of director variables to influence corporate illegal activity.

Finally, we extend recent work relating religiosity with legal accounting tactics such as earnings management (Callen et al., 2011; McGuire et al., 2012), voluntary financial restatements (Dyreng et al., 2012), and investment and growth rates (Hilary \& Hui, 2009) to the realm of illegal corporate activity. We also extend recent work on corporate illegal activity by examining two forms of illegal activity (i.e., fraudulent restatements and stock option backdating).

Specifically, we investigate the direct effect of religiosity on corporate illegal activity as well as the interaction effects of board size and board independence. We formally hypothesized that religiosity would negatively affect illegal corporate activity. Our results support this direct hypothesized relationship, particularly with regard to backdating. This result indicates that executives in firms located in more religious geographic areas are indeed influenced by the social norms of their environment. Although both backdating and reporting fraudulent financials are illegal, there are clearly important differences in the underlying reasons they occur. 
Moreover, we hypothesized that board size moderates the relationship between religiosity and illegal corporate activity. Our results did not support this hypothesis. In fact, larger boards actually increased the likelihood of illegal activity occurring. This result suggests that smaller boards may monitor executives more effectively with respect to these actions, perhaps because smaller boards encourage greater focus, engender member participation and cohesiveness, endure less social loafing, and encourage genuine debate among board members (Firstenberg \& Malkiel, 1994; Lipton \& Lorsch, 1992; Williams et al., 2005). They may also be more homogenous and easier to coordinate with regard to executive control mechanisms. Subsequent analyses show that this relationship is entirely associated with stock option backdating and not fraudulent financial reporting, further demonstrating underlying differences between these illegal activities.

We also hypothesized that board independence would moderate the relationship between religiosity and illegal corporate behavior. Our results support this hypothesis, as the relationship between religiosity and illegal activity becomes stronger as board independence increases. Once more, subsequent analyses clarify this relationship. It is actually only for firms restating fraudulent financials that this relationship holds. Once more, a difference between the two forms of illegal activity is evident.

\section{Implications}

Our results indicate that Eisenhardt (1989) was correct when she suggested that agency theory might fruitfully be combined with other theories to explain organizational phenomena. We integrate institutional theory with agency theory and demonstrate that social norms associated with religiosity can influence executive decisions to act illegally. This is a key finding, as some scholars (e.g., Ghoshal \& Moran, 1996) suggest that when some forms of opportunism are closely monitored, agents react by searching for other opportunities, even if they involve illegal actions. Our findings are consistent with institutional theory in that social norms can influence executive decision-making (North, 1990; Scott, 2001). For practitioners, our results have important implications. Considerable effort has gone into finding ways to keep executives from acting opportunistically. These efforts have primarily been aimed at aligning the interests of executives and shareholders through stock options and similar tools. Our findings suggest that those efforts may yield unintended consequences by inducing executives to game compensation systems. 


\section{Limitations and Future Research}

As with any study, ours has limitations that provide future research opportunities. First, our study focused on illegal corporate activity in the form of fraudulent financial reporting and stock option backdating. Scholars may consider whether other forms of opportunism are being used by executives and whether agency theory alone can explain these activities or if additional theories may be required. Scholars may also consider whether opportunism is even more multifaceted. It may be that there are different forms of opportunism that require different actions be taken to limit their damage.

A second limitation of our study was its focus on a single institutional measure (religiosity) and a limited number of board characteristics (board size and board independence). Institutions are not limited to those that are social in nature. Scholars may consider whether regulative and cultural-cognitive institutions may have as much of an effect on illegal corporate activity as do normative institutions. Additionally, other board and CEO characteristics such as power are ripe areas to be integrated with other theories. In particular, an examination of CEO religiosity and its influence on behaviors may yield interesting results.

Finally, our study focuses only on the CEO. Evidence suggests, however, that in many cases of illegal activity, other executives such as the CFO and COO are involved. There is also evidence in testimony to the Securities and Exchange Commission that managers below the executive rank have benefitted from and been involved in illegal activities. Research to help scholars better understand these actions would be beneficial.

\section{$\overline{\text { CONCLUSION }}$}

To date, scholars still understand too little regarding illegal corporate activity, despite its continued occurrence. Our study demonstrates that religiosity directly influences illegal corporate activity, but that this influence holds for stock option backdating and not fraudulent financial reporting. We further argued and found support for the moderating effect of board characteristics, though these relationships depend on the type of illegal activity examined. Our study confirms that corporate illegality is highly complex and that additional measures are necessary to prevent its occurrence. We hope that our research stimulates development in agency theory regarding how different forms of opportunism can be curtailed. We also hope that our research stimulates the integration of other theories with agency theory to provide a more complete understanding of how opportunism can be mitigated. 


\section{REFERENCES}

Aboody, D., \& Kasznik, R. (2000). CEO stock option awards and the timing of corporate voluntary disclosures. Journal of Accounting and Economics, 29, 73100 .

Abrahamson, E., \& Park, C. (1994). Concealment of organisational outcomes: An agency theory perspective. Academy of Management Journal, 5: 1302-1334.

Agresti, A. 2002. Categorical data analysis (2nd ed.). Hoboken, NJ: Wiley.

Amason, A. C., \& Sapienza, H. J. (1997). The effects of top management team size and interaction norms on cognitive and affective conflict. Journal of Management, 23, 495-516.

Arthaud-Day, M., Certo, S. T., Dalton, C. M., \& Dalton, D. R. (2006). A changing of the guard: Executive and director turnover following corporate financial restatements. Academy of Management Journal, 49, 1119-1136.

Baysinger, B. D., \& Butler, H. H. (1985). Corporate governance and the board of directors: Performance effects of changes in board composition. Journal of Law, Economics, and Organization, 1, 101-124.

Blake, J., \& Davis, K. (1964). Norms, values, and sanctions. In Handbook of modern sociology, Farris, R. E. L. Jr., (ed.). Chicago: Rand McNally, 456-484.

Callen, J. L., Morel, M., \& Richardson G. (2011). Do culture and religion mitigate earnings management? Evidence from a cross-country analysis. International Journal of Disclosure and Governance, 8, 103-121.

Cialdini, R. B., \& Goldstein, N. J. (2004). Social influence: Compliance and conformity. Annual Review of Psychology, 55, 591-621.

Coombs, J. E., \& Gilley, K. M. (2005). Stakeholder management as a predictor of CEO compensation: Main effects and interactions with financial performance. Strategic Management Journal, 26, 827-840.

Dalton, D. R., Daily, C. M., Ellstrand, A. E., \& Johnson, J. L. (1998). Meta-analytic reviews of board composition, leadership structure, and financial performance. Strategic Management Journal, 19, 269-290.

Dalton, D. R., Hitt, M. A., Certo, T. S., \& Dalton, C. M. (2007). The fundamental agency problem and its mitigation: Independence, equity, and the market for corporate control. Academy of Management Annals, 1, 1-64.

Denis, D. J., Hanouna, P., \& Sarin, A. (2006). Is there a dark side to incentive compensation? Journal of Corporate Finance, 12, 467-488. 
Devers, C. E., Cannella, A. A., Reilly, G. P., \& Yoder, M. E. (2007). Executive compensation: A multidisciplinary review of recent developments. Journal of Management, 33, 1016-1072.

Diaz, J. (2000). Religion and gambling in Sin-City: A statistical analysis of the relationship between religion and gambling patterns in Las Vegas residents. The Social Science Journal, 37, 453-458.

DiMaggio, P. J., \& Powell, W. W. (1983). The iron cage revisited: Institutional isomorphism and collective rationality in organizational fields. American Sociological Review, 48, 147-160.

Dohmen, T., Falk, A., Huffman, D., Sunde, U., Schupp, J., \& Wagner, G. G. (2011). Individual risk attitudes: Measurement, determinants and behavioral consequences. Journal of the European Economic Association, 9, 522-550.

Dow, G. K. (1987). The function of authority in transaction cost economics. Journal of Economic Behavior and Organization 8, 13-38.

Dyreng, S. D., Mayew, W. J., \& Williams, C. D. (2012). Religious social norms and corporate financial reporting. Journal of Business Finance and Accounting, 39, 845-875.

Eisenhardt, K. M. (1989). Agency theory: An assessment and review. Academy of Management Review, 14, 57-74.

Ezzamel, M. A., \& Watson, R. (1993). Organizational form, ownership structure, and corporate performance: A contextual empirical analysis of UK companies. British Journal of Management, 4(3), 161-176.

Fama, E. F. (1980). Agency problems and the theory of the firm. Journal of Political Economy, 88, 288-307.

Fama, E. F., \& Jensen, M. C. (1983). Separation of ownership and control. Journal of Law and Economics, 26, 301-325.

Finkelstein, S., \& Boyd, B. K. (1998). How much does the CEO matter: The role of managerial discretion in the setting of CEO compensation. Academy of Management Journal, 41, 179-199.

Firstenberg, P. B., \& Malkiel, B. G. (1994). The twenty-first century board-room: Who will be in charge? Sloan Management Review, 36, 27-35.

Gabbioneta, C., Greenwood, R., Mazzola, P., \& Minoja, M. (2013). The influence of the institutional context on corporate illegality. Accounting, Organizations and Society, 38, 484-504.

Ghoshal, S., \& Moran, P. (1996). Bad for practice: A critique of the transaction cost theory. Academy of Management Review, 21, 13-47. 
Grullon, G., Kanatas, G., \& Weston, J. Religion and corporate (mis)behavior. Unpublished working paper. Rice University.

Halek, M., \& Eisenhauer, J. (2011). Demography of risk aversion. Journal of Risk and Insurance, 68, 1-24.

Hambrick, D. C., \& Jackson, E. M. (2000). Outside directors with a stake: The linchpin in improving governance. California Management Review, 42, 108127.

Harris, J., \& Bromiley, P. (2007). Incentives to cheat: The influence of executive compensation and firm performance on financial misrepresentation. Organization Science, 18, 350-367.

Henderson, A. D., \& Fredrickson, J. W. (1996). Information-processing demands as a determinant of CEO compensation. Academy of Management Journal, 39, 575-606.

Heron, R. A., \& Lie, E. (2007). Does backdating explain the stock price pattern around executive stock option grants? Journal of Financial Economics, 83, 271295.

Heron, R. A., \& Lie, E. (2009). What fraction of stock option grants to top executives have been backdated or manipulated? Management Science, 55, 513-525.

Heron, R. A., Lie, E., \& Perry, T. (2007). On the use (and abuse) of stock option grants. Financial Analyst Journal, 63, 17-27.

Hilary, G., \& Hui, K. W. (2009). Does religion matter in corporate decision making in America? Journal of Financial Economics, 93, 455-473.

Hitt, M. A., Ahlstrom, D., Dacin, M. T., Levitas, E., \& Svobodina, L. (2004). The institutional effects on strategic alliance partner selection in transition economies: China vs. Russia. Organization Science, 15, 173-185.

Hoetker, G. (2007). The use of logit and probit models in strategic management research: Critical issues. Strategic Management Journal, 28, 331-343.

Iannaccone, L. R. (1998). Introduction to the economics of religion. Journal of Economic Literature, 36, 1465-1495.

Janney, J. J., \& Gove, S. (2011). Reputation and corporate social responsibility aberrations, trends, and hypocrisy: Reactions to firm choices in the stock option backdating scandal. Journal of Management Studies, 48, 1562-1585.

Jensen, M. C., \& Meckling, W. H. (1976). Theory of the firm: Managerial behavior, agency costs, and ownership structure. Journal of Financial Economics, 3, 305360 .

Katz, R. C., Santman, J., \& Lonero, P. (1994). Findings on the revised Morally Debatable Behaviors Scale. Journal of Psychology, 128(1), 15-21. 
Kennedy, E. J., \& Lawton, L. (1998). Religiousness and business ethics. Journal of Business Ethics, 17, 163-175

Kohlberg, L. (1984). Essays on moral development Vol. 2, the psychology of moral development. San Francisco, CA: Harper and Row.

Lie, E. (2005). On the timing of CEO stock option awards. Management Science, $51,802-812$.

Lipton, M., \& Lorsch, J. W. (1992). A modest proposal for improved corporate governance. Business Lawyer, 48, 59-77

Liu, E. Y. (2010). Are risk-taking persons less religious? Risk preference, religious affiliation, and religious participation in Taiwan. Journal for the Scientific Study of Religion, 49, 172-178.

Mazar, N., Amir, O., \& Ariely, D. (2008). The dishonesty of honest people: A theory of self-concept maintenance. Journal of Marketing Research, 45, 633-644.

McGuire, S. T., Omer, T. C., \& Sharp, N. Y. (2012). The impact of religion on financial reporting irregularities. The Accounting Review, 87, 645-673.

Miller, A. (2000). Going to Hell in Asia: The relationship between risk and religion in a cross-cultural setting. Review of Religious Research, 40, 5-18.

Miller, A. S., \& Hoffman, J. P. (1995). Risk and religion: An explanation of gender differences in religiosity. Journal for the Scientific Study of Religion, 34, 63-75.

Mizruchi, M. S. (1983). Who controls whom? An examination of the relation between management and board of directors in large American corporations. Academy of Management Journal, 8, 426-435.

Narayanan, M. P., Schipani, C. A., \& Seyhun, H. N. (2007). The economic impact of backdating of executive stock options. Michigan Law Review, 105, 1597-1641.

Narayanan, M. P., \& Seyhun, H. N. (2008). The dating game: Do managers designate option grant dates to increase their compensation? The Review of Financial Studies, 21, 1907-1945.

Ndofor, H. A., Wesley, C., \& Priem, R. L. (2015). Providing CEOs with opportunities to cheat. Journal of Management, 41, 1774-1797.

North, D. (1990). Institutions, institutional change and economic performance. Cambridge, UK: Cambridge University Press.

Noussair, C. N., Trautmann, S. T., van de Kuilen, G., \& Vellekoop, N. (2013). Risk aversion and religion. Journal of Risk and Uncertainty, 47, 165-183.

Ocasio, W. (1994). Political dynamics and the circulation of power: CEO succession in U.S. industrial corporations, 1960-1990. Administrative Science Quarterly, 39, 285-312. 
O’Connor, J. P., Priem, R. L., Coombs, J. E., \& Gilley, K. M. (2006). Do CEO stock options prevent or promote corporate accounting irregularities? Academy of Management Journal, 49, 483-500.

Parboteeah, K. P., Hoegl, M., \& Cullen, J. B. (2008). Ethics and religion: An empirical test of a multidimensional model. Journal of Business Ethics, 80, 387-398.

Pearce, J. A., \& Zahra, S. A. (1992). Board composition from a strategic contingency perspective. Journal of Management Studies, 29, 411-438.

Peng, M. W. (2003). Institutional transitions and strategic choices. Academy of Management Review, 28, 275-296.

Perrin, R. D. (2000). Religiosity and honesty: Continuing the search for the consequential dimension. Review of Religious Research, 41, 534-544.

Sanders, W. G., \& Hambrick, D. C. (2007). Swinging for the fences: The effects of CEO stock options on company risk taking and performance. Academy of Management Journal, 50, 1055-1078.

Scott, W. R. (2001). Institutions and organizations. Thousand Oaks, CA: Sage.

Shen, W. (2003). The dynamics of the CEO-board relationship: An evolutionary perspective. Academy of Management Review, 28, 466-476.

Sunstein, C. R. (1996). Social norms and social rules. Columbia Law Review, 96, 903-968.

Weaver, G. R., \& Agle, B. R. (2002). Religiosity and ethical behavior in organizations: A symbolic interactionist perspective. Academy of Management Review, 27, 7797.

Welch, M. R., Tittle, C. R., \& Petee, T. (1991). Religion and deviance among adult Catholics: A test of the "moral communities" hypothesis. Journal for the Scientific Study of Religion, 30, 159-172.

Wiersema, M. F., \& Bowen, H. P. (2009). The use of limited dependent variable techniques in strategy research: Issues and methods. Strategic Management Journal, 30, 679-692.

Williams, R. J., Fadil, P. A, \& Armstrong, R. W. (2005). Top management team tenure and corporate illegal activity: The moderating influence of board size. Journal of Managerial Issues, 17, 479-493.

Zahra, S. A., \& Pearce, J. A. (1989). Boards of directors and corporate financial performance: A review and integrative model. Journal of Management, 15, 291334.

Zahra, S. A., Priem, R. L., \& Rasheed, A. A. (2005). The antecedents and consequences of top management fraud. Journal of Management, 31, 803-828. 
Zhang, X., Bartol, K. M., Smith, K. G., Pfarrer, M. D., \& Khanin, D. M. (2008). CEOs on the edge: Earnings manipulation and stock-based incentive misalignment. Academy of Management Journal, 51, 241-258.

\section{BRIEF BIOGRAPHICAL SKETCH OF AUTHORS}

Joseph E. Coombs is an Associate Professor of Management and Academic Director for Entrepreneurship Programs in the School of Business at Virginia Commonwealth University where he teaches courses in entrepreneurship and strategic management. He received his doctorate from Temple University. $\mathrm{He}$ has held faculty positions at Rutgers University, James Madison University, the University of Richmond, and Texas A\&M University.

K. Matthew Gilley holds the Bill Greehey Chair in Ethics and Corporate Social Responsibility in the Greehey School of Business at St. Mary's University. He holds a doctorate in strategic management from the University of Texas at Arlington. His primary teaching and research interests are in the areas of ethical leadership, corporate responsibility, and bridging academic research and practice.

Joe O'Connor recently retired from the Marketing and Management Department after 11 years at the University of Texas at El Paso. Dr. O'Connor earned his Ph.D. in Management Science in 2005 from the University of Wisconsin - Milwaukee. Prior to joining academia, he spent 25 years as a senior leader in human resources for major corporations, as well as serving eight years on active duty with the United States Army.

Tim Thorley has a master's degree in Management from Virginia Commonwealth University and teaches Financial Literacy at Dixie High School in St. George, Utah. When he is not teaching, Tim is busy with his kids, reading, and working in his garden.

Dr. Curtis Wesley is an Assistant Professor of Strategy and Entrepreneurship at the University of Houston C.T. Bauer College of Business. His primary areas of interest are the positive organizational scholarship in corporate governance and entrepreneurship. He serves on the editorial board of the Journal of Management and has published in a variety of management outlets including the Journal of Management, Strategic Entrepreneurship Journal, and Business Ethics Quarterly. 